\title{
The entrepreneurial perceptions of strategy makers: Constructing an exploratory path in the pursuit of radical growth
}

\author{
Stern Neill , Jonathan L. York
}

\begin{abstract}
A B S T R A C T
For established firms, radical growth requires experimenting with new alternatives, which can test the boundaries of management's thinking. This study proposes that entrepreneurial perceptions of the strategic situation and market environment have a direct influence on corporate entrepreneurship (CE) strategy, which is strategy that supports new business development and renewal. The results indicate that strategy makers will pursue a more explorative CE strategy in situations framed as positive, less controllable and yet knowable, and in environments perceived as munificent and dynamic. Additionally, with explorative CE strategy comes a greater investment in radical growth (i.e., new lines of business). The paper concludes with a discussion of the study's implications in regards to the relationship between interpretation and strategy and the management of attention and meaning.
\end{abstract}

\section{Introduction}

Firms may pursue lower-yield growth based on strategy that derives from known parameters (e.g., capabilities, products, technologies and markets) or radical growth that stretches the business into new domains but may also strain or supplant existing knowledge and resources (Day, 2006; Treacy and Sims, 2004; Varadarajan, 2009). Venturing into the unknown requires a more exploratory approach by strategy makers that extends beyond existing products, markets and competencies. Explorative strategies seek change through experimentation with new alternatives, as opposed to exploitation strategies, which pursue incremental change that supplements existing alternatives. This study examines the exploration of new product-market spaces and firm competencies by strategy makers in existing firms, which is the domain of corporate entrepreneurship (CE) strategy.

To investigate CE strategy, this study examines how the entrepreneurial perceptions of individuals highly involved in strategy-making influences the degree to which the organization engages in innovation and renewal. Entrepreneurial perceptions are a way of conceiving that accounts for the subjective nature of opportunity construction and resource mobilization (Kor et al., 2007). The perceptions of executives perform an important function in the allocation of attention and how the firm interacts with its environment (Gavetti and Levinthal, 2000). CE strategy describes a predisposition to think and act in a particular manner, specifically as "a vision-directed, organization-wide reliance on entrepreneurial behavior that purposefully and continuously rejuvenates the organization and shapes the scope of its operations through the recognition and exploitation of entrepreneurial opportunity" (Ireland et al., 2009, p. 21). A potential ambiguity related to the domain of CE strategy is its relatedness to existing business operations and competencies (Sharma and Chrisman, 1999). However, several studies conceptualize CE based on the degree of newness in products, markets and/or competencies (Covin and Miles, 1999; Dess et al., 2003). The degree of newness captures the extent to which CE varies from exploitative to exploratory. This research pursues this further by conceptualizing exploration as a more radical form of $\mathrm{CE}$, while exploitation is an incremental form of CE strategy.

In the initial conceptualization, March (1991) argues that exploration and exploitation are essential yet incompatible. Exploration and exploitation are essential in that an organization that pursues explorative - to the exclusion of exploitative - strategies may never realize full returns; whereas, a strict exploitative strategy suffers from a tendency toward obsolescence, especially in a market environment. An ambidextrous organization balances these competing strategies (He and Wong, 2004; Tushman and O'Reilly, 1996); however, achieving such balance requires managing multiple paradoxes as each approach demands different organizational configurations (e.g., resources, procedures, strategies, schemas and culture).

Whichever the form of CE strategy (explorative or exploitive), a better understanding of what drives the form of CE is needed and has been called for (Dess et al., 2003). Prior research identifies organizational factors (i.e., resources, structures, behaviors, culture and leadership) that have an influence on CE (Guth and Ginsberg, 1990) and the specific pursuit of explorative strategies (Atuahene-Gima, 2005; Tellis et al., 2009; Voss et al., 2008; Zhou et al., 2005). Studies also 
indicate that environmental perception influences CE (Edelman and YliRenko, 2010; Simsek et al., 2007; Zahra, 1991, 1993); however, research has not examined how a strategy maker's entrepreneurial perception of both strategic situation and market environment influences the form of CE strategy and its impact on the pursuit of radical growth.

Ireland et al., (2009) propose that individual (pro-entrepreneurial) cognition and external environmental conditions influence the adoption of CE strategy. This paper continues this line of reasoning by specifically examining the effects of entrepreneurial perceptions. After all, it is this interpretation by strategy makers that translates into business strategy (Burke, 1984; Child, 1972) with interpretation mediating the objective environment and business venturing relationship (Edelman and Yli-Renko, 2010). What remains relatively unexplored and that this article seeks to address are the perceptual factors that underlie the form of CE behavior in terms of the degree of exploration.

This paper's contribution is in investigating the relationship between entrepreneurial perception and the explorative form of CE strategy. Specifically, this research examines how perceptions of situation and environment by strategy makers influence the path taken towards the most radical form of growth, the development of new lines of business. While perception can constrain response, it can also liberate strategy. To explore the relationship between strategy and business growth, the paper examines the extent to which a CE strategy experiments with new alternatives rather than supplements existing alternatives (i.e., exploitation). Therefore, the question guiding this research is: what role do perceptions perform in the more exploratory path to radical growth? In examining this question, the paper presents a conceptual framework and hypotheses, which are tested based on survey responses from senior managers. The paper concludes with a discussion of the implications this research brings to the theory and practice of corporate entrepreneurship.

\section{Conceptual framework and hypotheses}

The prevailing view in academic research is that business opportunity is discovered (Drucker, 1985; Shane and Venkataraman, 2000); however, a new view, predominately in the entrepreneurial field, is that opportunity is created in as much as it is found (Alvarez and Barney, 2007; Wood and McKinley, 2010). From the constructivist perspective, the individual is an active creator perceiving the context that influences strategic action, thereby constructing the very future that was envisioned. In attending to strategic issues, the decision maker both defines the current state and sets a course for responding (Ocasio, 1997). The tendency is to focus attention and experience on the near and familiar (Levinthal and March, 1993); however, such a convergence towards simplification constrains variability leading to inflexibility, myopia, and an inability to adapt (Miller, 1993). The key then becomes under what circumstances, and how, strategy makers construct an interpretation that permits new alternatives rather than simply adhering to known parameters.

There are real differences between objective and perceived conditions, which are likely due to what is noticed and how these conditions are interpreted (Doty et al., 2006). Indeed, perceptions may be more relevant to understanding strategy and ultimately performance than the actual facts of the situation. Evidence suggests that firms may actually benefit from inaccurate perceptions, which can promote strategic change despite the availability or precision of external cues (Sutcliffe, 1994; Sutcliffe and Weber, 2003). Thus, rather than examine the impact of the objective environment on the choice of business unit strategy, this paper examines the influence that perceptions have on the direction of CE strategy.

This paper proposes that the entrepreneurial perceptions of strategy makers will influence the form of CE strategy. To examine this relationship, the current study investigates antecedent conditions of explorative CE strategy by examining the perceptions of strategy makers. Strategy makers enact a plausible construction of the situation and environment, which serves as the narrative for potential action (Weick, 1995). The opportunities available to the firm are regulated by the perceptions of its entrepreneurs (Penrose, 1959) which explains why perceptions are (or could be) entrepreneurial. This paper examines two distinct, but possibly interconnected perceptual domains: situation and environment. The perceived situation describes beliefs about the immediate decision-making context that the individual is addressing, while the perceived environment describes beliefs about business conditions that are external to the firm. This paper examines how perceptions influence the explorative form of CE strategy, as construed by the organization's strategy makers. Further, this paper posits a positive effect of explorative CE strategy on radical growth, by examining investments in new, unrelated lines of business (Fig. 1).

\subsection{Perceived situation and exploration}

The perceived situation concerns the executive's subjective views on the current strategic decision-making context within the organization. Three elements - valence, controllability and uncertainty have been used to describe situations in prior studies. Dutton and Jackson (1987) propose threats as situations that are negative where a loss is likely and there is little control, while opportunities are positive situations with likely gains and a degree of control. However, Thomas and McDaniel (1990) find that positive-negative and gainloss are empirically indistinct; therefore, two measures that describe the situation are valence and controllably. Valence captures whether the immediate situation is viewed positively (e.g., opportunity) or negatively (e.g., threat) (Mittal et al., 2002). Controllability gauges the extent to which decision makers view the situation as manageable

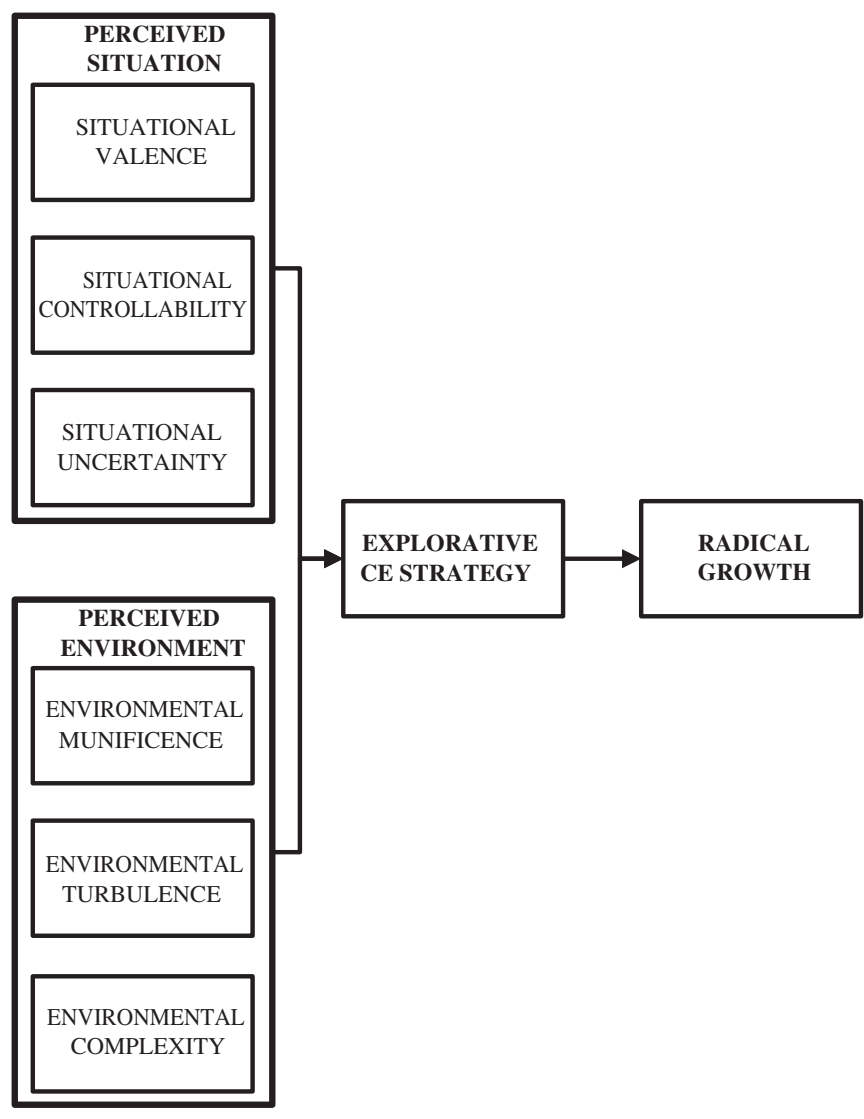

Fig. 1. Conceptual model on the entrepreneurial perceptions of strategy makers. 
based on existing resources (Sutcliffe and Huber, 1998). Other researchers have examined uncertainty during decision-making (Achrol and Stern, 1988; Sitkin and Pablo, 1992). Tushman and Nadler (1978, p. 615) define uncertainty as "the difference between information processed and information required to complete a task." Together, these three dimensions (i.e., valence, controllability and uncertainty) constitute the strategy maker's cognitive construction of the strategic decision situation and are proposed to have a direct effect on the firm's pursuit of an explorative CE strategy.

A situation with a positive valence is framed as a potential opportunity or gain for the firm. In favorable situations, managers are more likely to develop new competencies (Atuahene-Gima, 2005) and implement a greater magnitude of response (White et al., 2003), particularly directed at the market (Chattopadhyay et al., 2001; Dutton and Jackson, 1987). However, if decision makers perceive that the firm already has adequate resources to address the situation (i.e., controllability), the tendency is to pursue familiar paths based on proven ideas and capabilities (Sutcliffe and Weber, 2003). Furthermore, under conditions of uncertainty, decision makers are less able to gauge the situation, its impact, or how to respond (Milliken, 1987). Given a high degree of unforeseeable uncertainty, managers will adhere to tried-and-true approaches that have proven successful (Sitkin and Pablo, 1992) - in other words, less likely to pursue explorative strategies. Thus, experimentation with new alternatives and pursuit of a more explorative CE strategy occurs in situations that are viewed with greater optimism, insufficient internal resources, and more certainty.

Hypothesis 1a. A positive situational valence is positively associated with an explorative CE strategy.

Hypothesis 1b. Situational controllability is negatively associated with an explorative CE strategy.

Hypothesis 1c. Situational uncertainty is negatively associated with an explorative CE strategy.

\subsection{Perceived environment and exploration}

The perceived environment entails subjective views of the market. Dess and Beard (1984) describe the environment in which the firm conducts its business along three dimensions: munificence, turbulence and complexity. Munificence captures the capacity of the market to support sustained growth (Castrogiovanni, 1991). Turbulence gauges the level of market instability in the firm's customer, competitor and technological environments (Jaworski and Kohli, 1993), while complexity is the degree to which there are multiple, diverse and interdependent elements in the environment (Huber and Daft, 1987). It should be noted that each of these represents perceptions of the external business environment, rather than an objective state.

In munificent environments, slack external resources allow the firm to experiment rather than focus solely on survival strategies (Castrogiovanni, 1991), which ultimately promotes new business creation (Edelman and Yli-Renko, 2010; Simsek et al., 2007; Zahra, 1993). Viewing the external environment as dynamic encourages exploration of new ideas and alternatives rather than familiar thinking and strategy (Davis et al., 1991; Neill et al., 2007; Zhou et al., 2005). This ultimately promotes organizational innovation and transformation (Lumpkin and Dess, 1996; Zahra, 1991, 1993). Similarly, construing the environment as complex provides the firm with a broader canvas upon which to explore new alternatives rather than constraining strategy to one-dimensional possibilities (Neill and Rose, 2006), which will act to encourage the entrepreneurial nature of business strategy (Simsek et al., 2007; Zahra, 1991). In sum, firms experiment with new strategies and resources (i.e., engage in explorative CE strategy) when the external environment is perceived as munificent, turbulent and complex.

Hypothesis 2a. Environmental munificence is positively associated with an explorative CE strategy.

Hypothesis 2b. Environmental turbulence is positively associated with an explorative CE strategy.

Hypothesis 2c. Environmental complexity is positively associated with an explorative CE strategy.

\subsection{Exploration and radical growth}

Rather than refining existing capabilities, products, technologies and markets, which is the hallmark of incremental forms of growth, exploration requires that strategy makers venture into unknown territory. Pursuit of new, unrelated lines of business demands that strategy makers develop new approaches and rely less on existing resources. Investment in new, unrelated business requires the firm to stretch existing capabilities and venture into relatively unknown market spaces (Day, 2006). Thus, the decision to invest in radical growth flows from the pursuit of an explorative CE strategy.

Hypothesis 3. An explorative CE strategy is positively associated with investment in radical growth.

\section{Method}

To test the hypotheses, both newly developed and established scales were used (see Appendix for scale content and source). Data were gathered from business executives. To obtain reliable measures, face validity, item analyses and Cronbach's alpha were examined. Structural equation modeling was employed to test the hypotheses.

\subsection{Measurement development}

Development of the situational valence and explorative $\mathrm{CE}$ strategy measures began with conceptual definitions developed through a review of the literature. Next, an item pool was generated and reviewed by a panel of five domain experts with expertise in organizational research. To purify the scales and assess unidimensionality of scale items, a pilot study was then undertaken using a sample of 32 senior managers highly involved in strategic decisions (average of 5.72 on a seven-point scale) with an average of six or more years of experience and from a mix of industries (62.5\% services, $28.1 \%$ manufacturing, and 9.4\% other). Using these responses, unidimensionality was assessed based on a) factor loadings of at least .50, b) item-to-total correlations of at least $.35, \mathrm{c}$ ) average inter-item correlations of at least .15, and d) Cronbach's alpha of at least 0.70 . The measures were trimmed and revised after ensuring that face validity would not be compromised.

\subsection{Data collection}

To assess the measurement of and relationships among the study's constructs, data were collected from key informants representing separate business units. The instrument was distributed by mail and directed to individuals directly involved in the business unit's strategic decisions and who were most likely to have influence on the form of CE strategy. Respondents were instructed to provide answers based on a current or recent situation where a) an important issue was under consideration, b) multiple individuals - including the respondent - were involved, and c) the outcome might significantly affect customer relationships and/or perceptions of value. To aid generalizability, a broad sampling frame of experienced executives from a mix of industries was acquired by contacting two associations 
(supply management and information technology). Each individual was asked a series of background questions in order to confirm that the appropriate respondent was reached. Three contacts were made (two letters with a questionnaire and a reminder postcard). The first sample represented 793 senior-level purchasing executives of which 91 responded (response rate $=11.5 \%$ ), while the second sample represented 652 senior-level marketing executives of which 76 responded ( response rate $=11.7 \%$ ).

To assess data quality, responses were examined for key informant competency, non-response bias, data poolability, and commonmethods bias. To ensure key informant competency, only those respondents with substantial involvement in the business unit's strategic decisions (four or higher on a seven-point scale) were retained, which lead to the removal of 20 respondents. The remaining informants were executives (17.69\% chief executive officer, $27.89 \%$ vice president, $46.26 \%$, middle management and $8.16 \%$ other) with an average of six or more years of experience and considerable involvement in strategic decisions (average of 5.49 on a seven-point scale) with their organization. Respondents also represented a broad mix of industries (32.7\% services, 36.1\% manufacturing, and $31.3 \%$ other). Nonresponse bias did not appear to be an issue, as there were no significant differences among the variables between early and late returns (cf., Armstrong and Overton, 1977). A Box test confirmed that the relationships among variables were not different across the two groups (Box's $\mathrm{M}=40.07, \mathrm{~F}_{28}, 46432=1.34, \mathrm{p}=.11$ ) indicating that it is appropriate to combine the samples. To test for common methods bias, a Harman's one-factor test was performed (cf., Podsakoff and Organ, 1986). The test did not indicate a common source of variance, as the factor structure is confirmed with the first factor accounting for $14.93 \%$ of the variance.

\section{Results}

To assess measurement reliability, the same procedure as described in the Measurement development section was followed. Based on this procedure, all scales exhibited acceptable reliabilities. To determine that each measure was empirically distinct, discriminant validity was assessed and supported in all cases, as the square of the parameter estimate (phi) between each pair of constructs was less than the mean of the pair's average variance extracted (AVE) estimates (Fornell and Larcker, 1981). Table 1 presents the internal consistency estimates, summary statistics, and correlations among constructs.

As a test of the study's hypotheses, structural equation modeling was used. To control for measurement error, each loading estimate (lambda) was fixed as the square root of the reliability estimate, and

Table 1

Measurement and structural results.

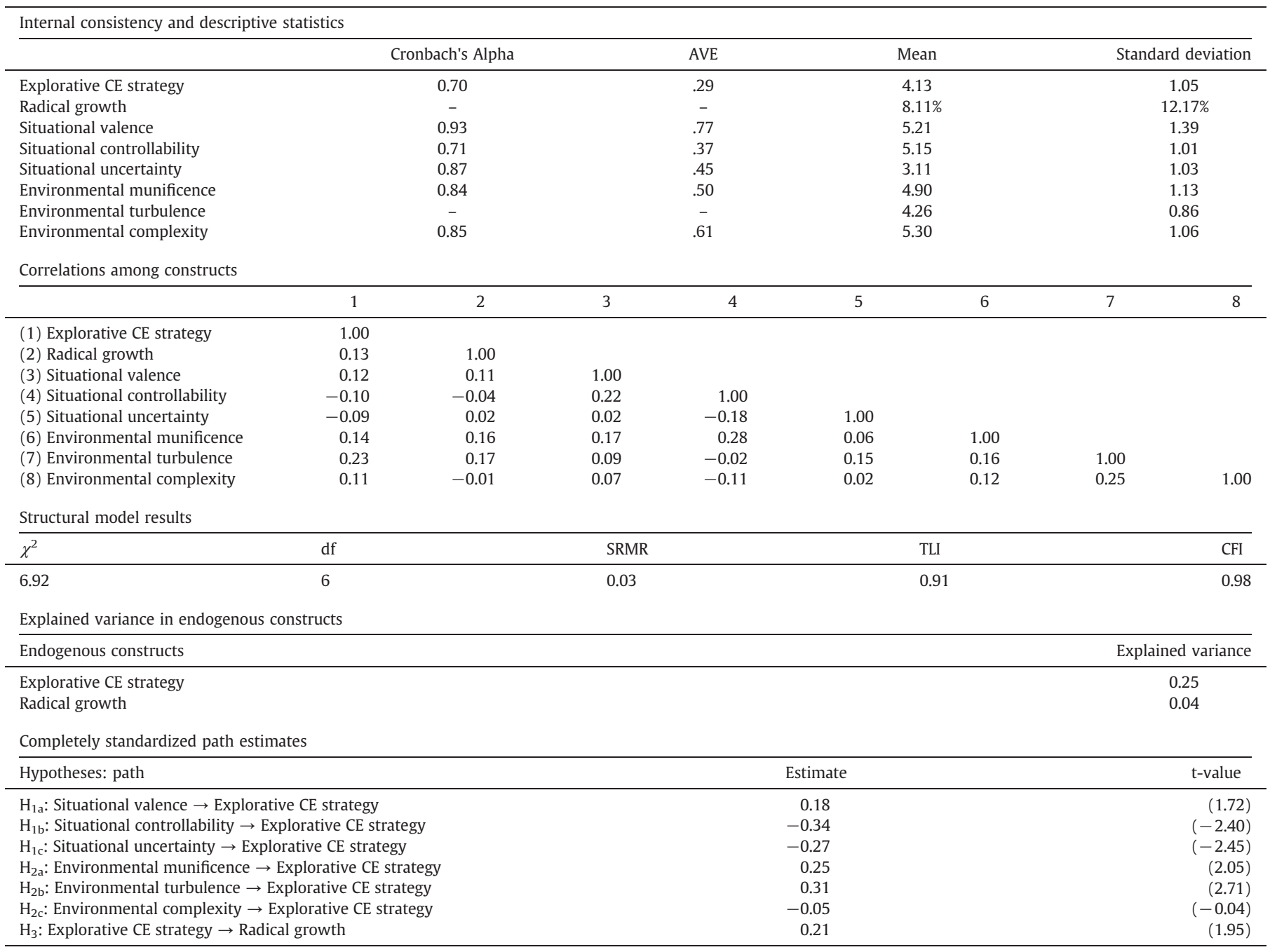

NOTE: $A V E=$ average variance extracted; $\mathrm{df}=$ degrees of freedom; SRMR = standardized root mean square residual; TLI = Tucker-Lewis index; CFI = comparative fit index. T-values of 1.65 or greater are significant at the .05 level; t-values of 2.33 or greater are significant at the .01 level. 
the error term (theta) was set to one minus the reliability (Hair et al., 2006). Given that environmental turbulence is a composite measure, a reliability of .80 was assumed and the error term was fixed at .20 . Table 1 contains the structural model results. The overall fit of the structural model was acceptable $\left(\chi^{2}=6.92\right.$ with 6 d.f.; SRMR $=.03$; $\mathrm{TLI}=.91 ; \mathrm{CFI}=.98)$ and six of seven paths are statistically significant ( $p<.05$ or better). $\mathrm{H}_{1}$ predicted that perceived situation is related to an explorative $\mathrm{CE}$ strategy and is supported for situational valence $\left(\mathrm{H}_{1 \mathrm{a}} ; \gamma=.18, \mathrm{p}<.05\right)$, situational controllability $\left(\mathrm{H}_{1 \mathrm{~b}} ; \gamma=-.34\right.$, $\mathrm{p}<.01)$, and situational uncertainty $\left(\mathrm{H}_{1 \mathrm{c}} ; \gamma=-.27, \mathrm{p}<.01\right) . \mathrm{H}_{2}$, which posited that the perceived environment is related to an explorative $\mathrm{CE}$ strategy, was supported for environmental munificence $\left(\mathrm{H}_{2 \mathrm{a}} ; \gamma=.25, \mathrm{p}<.05\right)$ and environmental turbulence $\left(\mathrm{H}_{2 \mathrm{~b}}\right.$; $\gamma=.31, \mathrm{p}<.01)$, but not environmental complexity $\left(\mathrm{H}_{2 c} ; \gamma=-.05\right.$, $\mathrm{p}>.05)$. The results indicate that an explorative $\mathrm{CE}$ strategy is positively related to the pursuit of radical growth $\left(\mathrm{H}_{3} ; \beta=.21\right.$, $\mathrm{p}<.05$ ). In total, the structural equations account for a quarter of the variance in explorative CE strategy and less than five percent of the variance in radical growth. Except for $\mathrm{H}_{2 \mathrm{C}}$, the independent effects $\left(\mathrm{H}_{1}-\mathrm{H}_{3}\right)$ are supported based on model fit, path significance, and variance explained.

\section{Discussion}

There are two paths to CE strategy: one demands a leap into the unknown by experimenting with new alternatives (i.e., explorative), while the other requires an incremental step working within known parameters (i.e., exploitative). Growth is the destination for either path; however, deviation from tried-and-true approaches is regulated by how strategic issues are perceived. Exploration requires a positive mindset and acceptance that the unfamiliar is not unknowable. This finding lends additional support to the business benefits of humble optimism (Sutcliffe and Weber, 2003). Consistent with the findings on strategic change by Wiersema and Bantel (1993), the pursuit of explorative CE strategy occurs when the firm is cognizant of a munificent and dynamic, but not necessarily a complex environment. Exploitation, on the other hand, is a seemingly more reliable path approached from a perspective of familiarity, especially in times of uncertainty and in environments perceived as scarce and stable.

As this study demonstrates, these entrepreneurial perceptual expressions influence how business development and renewal manifest. The results also support that firms which take an exploratory path that diverges from familiar ways of thinking and doing will invest more heavily in radical growth. In regards to the corporate entrepreneurship literature, this paper's findings suggest that interpretation has a direct effect on the form of CE strategy. In doing so, the paper provides a more expansive view by examining dimensions of both the perceived situation and environment. It is the entrepreneurial perceptions of strategy makers - in terms of the perceived situation and environment - that shape the form of $\mathrm{CE}$ strategy towards more exploratory pursuits and the eventual realization of radical growth.

This paper examines how entrepreneurial perceptions influence strategy; however, it offers different results than might be expected from prospect (Kahneman and Tversky, 1979) and threat-rigidity (Staw et al., 1981) theories. According to prospect theory, individuals will be less risk averse when faced with a likely loss, while threatrigidly maintains that the threat of a likely loss leads to inflexibility and risk aversion (Staw et al., 1981). Yet, several studies demonstrate that past success leads to an increased willingness to take risk (Osborn and Jackson, 1988; Thaler and Johnson, 1990). To account for this contradiction in results, several arguments have been proposed that the effect of framing on risk behavior is contingent upon risk propensities and perceptions (Sitkin and Pablo, 1992), causal attribution (Forlani and Walker, 2003), and organizational routines and resources (Chattopadhyay et al., 2001). However, it is important to note that both prospect theory and threat-rigidity emphasize response to threats. Chattopadhyay et al. (2001) confirm that neither theory explains corresponding effects for opportunities and surmise that organizational response to opportunities may be domain specific. Explaining the construction of opportunity requires alternative theory, which this paper seeks to support.

\subsection{Opportunities for future research and limitations}

While explorative and exploitative CE strategies require different kinds of perceptions, the challenge for organizations is to experiment with new alternatives while also sufficiently reaping the rewards once new territories are charted. This study's results suggest that perception may precipitate the explorative-exploitative duality in that interpretation may constrain the business unit to pursue one strategy over the other. Several studies suggest that the key to balancing these competing strategies is contingent upon the firm's knowledge-based capabilities (Auh and Menguc, 2005; Kyriakopoulos and Moorman, 2004; Wu and Shanley, 2009). Clearly, there remain multiple avenues of research in how to cognitively balance the potential trade-offs and apparent paradoxes inherent in explorative and exploitative CE strategies in order to achieve optimal outcomes.

In general, more research is needed that examines the effect of entrepreneurial perceptions. A thorough understanding of perceptions should examine antecedent conditions and the interactions among situation and environment. For example, Achrol and Stern (1988) provide evidence that environmental perceptions effect decision-making uncertainty. There may be additional ways in which situational and environmental perceptions are interwoven. Studies on organizational factors have posited that firm strategy and structure influence the focus of attention (Ocasio, 1997) and interpretations of the environment (Doty et al., 2006; Sutcliffe, 1994; Sutcliffe and Huber, 1998). There may indeed be recursive effects with organizational factors influencing entrepreneurial perceptions - and entrepreneurial perceptions, in turn, shaping organizational design. In general, research that captures the effects of and interrelationships among organizational factors on entrepreneurial perceptions would further understanding of the construction and function of interpretive mechanisms on CE strategy and business growth. In future research, interactions among situational and environmental perceptions offers rich possibilities, including the consideration of other contextualization variables (e.g., temporal framing, risk perceptions and causal attributions) and organizational factors (e.g., resource availability, control mechanisms, and routines).

Future research might also examine the cognitive capabilities that enable and prompt experimentation with meaning, understanding, and solutions. While this study has examined how managers perceive the situation and environment, additional research might further explore how perceptions of firm resources affect business development and renewal, as proposed by Danneels (2011). The established firm entering unfamiliar territory needs to be less rigid in how it views the world (Gavetti and Rivkin, 2007), be able to take leaps based on peripheral cues (Day and Schoemaker, 2006), and, in effect, develop a more entrepreneurial mindset (McGrath and MacMillan, 2000). Development of an entrepreneurial strategic vision (Ireland et al., 2009) may be partially determined by perceptions, which allow an organization to think and act opportunistically in the face of the unknown (Sommer et al., 2009) and despite perceived risks (Forlani and Walker, 2003; Sitkin and Pablo, 1992). Furthermore, ventures into the unknown may require executives to develop totally different approaches to thinking. Read and colleagues (2009) demonstrate how expert entrepreneurs use effectual logic (rather than reliance on market research precision) to construct opportunity in the face of uncertainty. With entrepreneurial thinking, the environment is endogenous; the unexpected represents opportunity; and the future 
is opportunistically co-created with stakeholders (Read et al., 2009). Examining relationships between entrepreneurial cognitive capabilities and strategy presents an interesting avenue of research in corporate entrepreneurship.

This paper's limitations should be acknowledged. First, reliance on cross-sectional data warrants caution in interpreting the results. A second limitation is that data collection was restricted to two industries (supply management and information technology) and respondents only represented senior-level purchasing and marketing executives. While efforts were undertaken to ensure that respondents were qualified, biases may be introduced based on the sample frame.

\subsection{Managerial implications}

Broadly, this research begins to inform executives on how to manage growth through the management of attention and meaning. Assuming that strategy makers need not perceive a strategic issue accurately in order to prosper from it, then strategies can be advanced by perceiving and communicating situations and environments in ways that promote long-term goals. If it is not the objective environment determining the route to strategy and growth, then the key becomes how to manage what is noticed and how it is interpreted in order to shape the construction of opportunity. This study's findings suggest how the firm may pursue one path over the other through the management of attention and meaning.

While managers may be tempted to favor either exploration or exploitation, firms are advised not to rely on a single path (Levinthal and March, 1993; March, 1991). Incremental innovation should not be overlooked as a growth strategy (Varadarajan, 2009); however, exploitation without exploration means that the firm concedes radically new opportunities to its competitors. And yet the tendency is for exploitation strategies to push out explorative strategies, which have more unpredictable and remote outcomes (Levinthal and March, 1993; March, 1991). This is particularly the case at the business unit level where each strategy competes for limited resources (Gupta et al., 2006), including cognitive bandwidth.

The more difficult issue for managers is how to encourage consideration of and experimentation with new alternatives despite prevailing situational or environmental perceptions. A focus on certainty, for example, leads individuals to "cling to familiar, predictable, and certain as their ways of thinking about the world" (Sorrentino and Roney, 2000, p. 4). Overcoming inertial tendencies is a great challenge given that explorative CE strategies are, by nature, not certain. With equal tendencies to view change as threatening and an unwillingness to perceive a situation as uncontrollable, it is of little wonder that firms are unable to pursue more radical forms of growth. The challenge for the manager is then to shift perception to a more exploratory course that is favorable to radical growth.

\section{Conclusion}

Entrepreneurial perceptions influence the strategies that affect growth. This study describes the manner in which situation and environment are perceived and how this perception influences the trajectory of the business unit's strategy. The findings suggest that the road less traveled is taken when the situation is viewed as an opportunity with an understanding that though the firm may not have all the necessary resources it has sufficient knowledge to explore new alternatives. Environments perceived as abundant and dynamic also encourage exploration. While the explorative route is an unknown path, it is one that promotes radical growth through new lines of business. While more research is needed, the current study contributes to understanding the relationship between entrepreneurial perception and corporate entrepreneurship strategy.

\section{Appendix. Scale content and sources}

\begin{tabular}{|c|c|c|}
\hline Construct & Content of scale items & Source \\
\hline Radical Growth ${ }^{\mathrm{a}}$ & $\begin{array}{l}\text { Percentage of expected business unit growth in } \\
\text { next five years from new lines of business }\end{array}$ & $\begin{array}{l}\text { Treacy and } \\
\text { Sims } 2004\end{array}$ \\
\hline $\begin{array}{c}\text { Explorative CE } \\
\text { Strategy }^{\mathrm{b}}\end{array}$ & $\begin{array}{l}\text { Apply current expertise-develop new } \\
\text { knowledge and/or skills, focus on operational } \\
\text { excellence-focus on product/service innovation, } \\
\text { refine current strategy-experiment with new } \\
\text { strategy, invest in current resources-invest in } \\
\text { new resources, research existing markets- } \\
\text { research emerging markets, use existing } \\
\text { technologies-develop new technologies }\end{array}$ & New scale \\
\hline $\begin{array}{r}\text { Situational } \\
\text { Valence }^{\mathrm{b}}\end{array}$ & $\begin{array}{l}\text { Loss-gain, threat-opportunity, negative } \\
\text { prospect-growth prospect, declining return- } \\
\text { positive return, disadvantage-advantage, crisis- } \\
\text { opening, unfavorable circumstance-favorable } \\
\text { circumstance }\end{array}$ & New scale \\
\hline $\begin{array}{l}\text { Situational } \\
\quad \text { Controllability }^{\mathrm{c}}\end{array}$ & $\begin{array}{l}\text { Resources are accessible, have the competencies, } \\
\text { can be controlled, can manage this situation, } \\
\text { places the firm in jeopardy ( } r) \text {, response is } \\
\text { constrained }(r)\end{array}$ & $\begin{array}{l}\text { Sutcliffe and } \\
\text { Huber } 1998\end{array}$ \\
\hline $\begin{array}{l}\text { Situational } \\
\text { Uncertainty }^{\mathrm{c}}\end{array}$ & $\begin{array}{l}\text { Situation is unpredictable, do not understand } \\
\text { how situation changing, uncertain how aspects } \\
\text { interrelated, unable to predict, difficult to } \\
\text { determine impact, uncertain of the effect, unable } \\
\text { to predict consequences, uncertain of responses, } \\
\text { difficult to determine alternatives }\end{array}$ & $\begin{array}{l}\text { Doty et al. } \\
2006\end{array}$ \\
\hline $\begin{array}{l}\text { Environmental } \\
\text { Munificence }^{\mathrm{c}}\end{array}$ & $\begin{array}{l}\text { Demand is growing, resources are easily } \\
\text { accessible, sales have been growing, total value } \\
\text { of assets is declining (r), capital expenditures are } \\
\text { growing, marketing opportunities are very } \\
\text { favorable }\end{array}$ & $\begin{array}{l}\text { Sutcliffe } \\
1994\end{array}$ \\
\hline $\begin{array}{l}\text { Environmental } \\
\text { Turbulence }^{\mathrm{c}}\end{array}$ & $\begin{array}{l}\text { Competition is cutthroat, new competitive move, } \\
\text { competitors are relatively weak (r), technology } \\
\text { is changing rapidly, rate of technological change } \\
\text { has increased, technological developments are } \\
\text { rather minor (r), new customers tend to have } \\
\text { different needs, cater to the same customers (r), } \\
\text { customers' preferences change }\end{array}$ & $\begin{array}{l}\text { Jaworski and } \\
\text { Kohli } 1993\end{array}$ \\
\hline $\begin{array}{l}\text { Environmental } \\
\text { Complexityc }^{c}\end{array}$ & $\begin{array}{l}\text { We operate in a complex environment, } \\
\text { numerous elements of the environment are } \\
\text { relevant, environment composed of diverse } \\
\text { elements, environmental elements have } \\
\text { interdependencies }\end{array}$ & $\begin{array}{l}\text { Sutcliffe and } \\
\text { Weber } 2003\end{array}$ \\
\hline
\end{tabular}

(r) Reverse coded.

a Figure derived based on allocation of expected business unit growth using a constant-sum scale of $100 \%$ to the following: customer share gain, market share gain, product/service development, market development, and new lines of business.

b Seven point semantic differential scale.

c Seven-point agree-disagree scale.

\section{References}

Achrol RS, Stern LW. Environmental determinants of decision-making uncertainty in marketing channels. J Mark Res 1988;25(1):36-50.

Alvarez SA, Barney JB. Discovery and creation: alternative theories of entrepreneurial action. Strateg Entrep J 2007;1:11-26.

Armstrong JS, Overton TS. Estimating nonresponse bias in mail surveys. J Mark Res 1977; 14(3):396-402.

Atuahene-Gima K. Resolving the capability-rigidity paradox in new product innovation. J Mark 2005;69(4):61-83.

Auh S, Menguc B. Balancing exploration and exploitation: the moderating role of competitive intensity. J Bus Res 2005;58(12):1652-61.

Burke MC. Strategic choice and marketing managers: an examination of business-level marketing objectives. J Mark Res 1984;21(4):345.

Castrogiovanni GJ. Environmental munificence: a theoretical assessment. Acad Manage Rev 1991;16(3):542-65.

Chattopadhyay P, Glick WH, Huber GP. Organizational actions in response to threats and opportunities. Acad Manage J 2001;44(5):937-55.

Child J. Organizational structure, environment and performance: the role of strategic choice. Sociology 1972;6(1):1-22.

Covin JG, Miles MP. Corporate entrepreneurship and the pursuit of competitive advantage. Entrep Theory Pract 1999;23(3):47-63.

Danneels E. Trying to become a different type of company: dynamic capability at Smith Corona. Strateg Manage J 2011;32(1):1-31. 
Davis D, Morris M, Allen J. Perceived environmental turbulence and its effect on selected entrepreneurship, marketing, and organizational characteristics in industrial firms. J Acad Mark Sci 1991;19(1):43-51.

Day GS. Closing the growth gap: balancing "big i" and "small i" innovation. Market Science Institute Reports, Number 06-121. Cambridge, MA: Marketing Science Institute; 2006.

Day GS, Schoemaker PJH. Peripheral vision: detecting the weak signals that can make or break your company. Boston, MA: Harvard Business School Press; 2006.

Dess GG, Beard DW. Dimensions of organizational task environments. Adm Sci Q 1984;29:52-73.

Dess GG, Ireland RD, Zahra SA, Floyd SW, Janney JJ, Lane PJ. Emerging issues in corporate entrepreneurship. J Manag 2003;29(3):351-78

Doty DH, Bhattacharya M, Wheatley KK, Sutcliffe KM. Divergence between informant and archival measures of the environment: real differences, artifact, or perceptual error? J Bus Res 2006;59(2):268-77.

Drucker PF. Innovation and entrepreneurship: practice and principles. New York: Harper \& Row; 1985

Dutton JE, Jackson SE. Categorizing strategic issues: links to organizational action. Acad Manage Rev 1987:12(1):76-90.

Edelman L, Yli-Renko H. The impact of environment and entrepreneurial perceptions on venture-creation efforts: bridging the discovery and creation views of entrepreneurship. Entrep Theory Pract 2010;34(5):833-56.

Forlani D, Walker OC. Valenced attributions and risk in new-product decisions: how why indicates what's next. Psychol Mark 2003;20(5):395-492.

Fornell C, Larcker DF. Evaluating structural equation models with unobservable variables and measurement error. J Mark Res 1981;18(1):39-50.

Gavetti G, Levinthal D. Looking forward and looking backward: cognitive and experiential search. Adm Sci Q 2000;45(1):113-37.

Gavetti G, Rivkin J. On the origin of strategy: action and cognition over time. Organ Sci 2007;18(3):420-39.

Gupta AK, Smith KG, Shalley CE. The interplay between exploration and exploitation. Acad Manage J 2006;49(4):693-706

Guth WD, Ginsberg A. Guest editors' introduction: corporate entrepreneurship. Strateg Manage J 1990;11(5):5-15.

Hair JF, Black WC, Babin BJ, Anderson RE, Tatham RL. Multivariate data analysis, 6th ed. Upper Saddle River, NJ: Pearson Prentice Hall; 2006.

He Z, Wong P. Exploration vs. exploitation: an empirical test of the ambidexterity hypothesis. Organ Sci 2004;15(4):481-94.

Huber GP, Daft RL. The information environments of organizations. In: Jablin FM, editor Handbook of Organizational Communication. Newbury Park, CA: Sage; 1987. p. 131-65.

Ireland RD, Covin JG, Kuratko DF. Conceptualizing corporate entrepreneurship strategy. Entrep Theory Pract 2009;33(1):19-46.

Jaworski BJ, Kohli AK. Market orientation: antecedents and consequences. J Mark 1993;57(3):53-70.

Kahneman D, Tversky A. Prospect theory: an analysis of decision under risk Econometrica 1979;47(2):263-91

Kor YY, Mahoney JT, Michael SC. Resources, capabilities and entrepreneurial perceptions. J Manag Stud 2007;44(7):1187-212.

Kyriakopoulos K, Moorman C. Tradeoffs in marketing exploitation strategies: the overlooked role of market orientation. Int J Res Mark 2004;21(3):219-40.

Levinthal DA, March JG. The myopia of learning. Strateg Manage J 1993;14:95-112.

Lumpkin GT, Dess GG. Clarifying the entrepreneurial orientation construct and linking it to performance. Acad Manage Rev 1996;21(1):135-72.

March JG. Exploration and exploitation in organizational learning. Organ Sci 1991;2(1): 71-87.

McGrath RG, MacMillan I. The entrepreneurial mindset: strategies for continuously creating opportunity in an age of uncertainty. Boston, MA: Harvard Business Schoo Press; 2000.

Miller D. The architecture of simplicity. Acad Manage Rev 1993;18(1):116-38.

Milliken FJ. Three types of perceived uncertainty about the environment: state, effect, and response uncertainty. Acad Manage Rev 1987;12(1):133-43.

Mittal V, Ross WT, Tsiros M. The role of issue valence and issue capability in determining effort investment. J Mark Res 2002;39(4):455-68.

Neill S, Rose GM. The effect of strategic complexity on marketing strategy and organizational performance. J Bus Res 2006;59(1):1-10.
Neill S, McKee D, Rose GM. Developing the organization's sensemaking capability: precursor to an adaptive strategic marketing response. Ind Mark Manage 2007;36(6):731-44.

Ocasio W. Towards an attention-based view of the firm. Strateg Manage J 1997;18: 187-206.

Osborn RN, Jackson DH. Leaders, riverboat gamblers, or purposeful unintended consequences in the management of complex, dangerous technologies. Acad Manage J 1988;31(4):924-47.

Penrose E. The theory of the growth of the firm. New York: Wiley; 1959

Podsakoff PM, Organ DW. Self-reports in organizational research: problems and prospects. J Manag 1986;12(4):531-44.

Read S, Dew N, Sarasvathy SD, Song M, Wiltbank R. Marketing under uncertainty: the logic of an effectual approach. J Mark 2009;73(3):1-18

Shane $S$, Venkataraman $S$. The promise of entrepreneurship as a field of research. Acad Manage Rev 2000;25(1):217-26.

Sharma P, Chrisman JJ. Toward a reconciliation of the definitional issues in the field of corporate entrepreneurship. Entrep Theory Pract 1999;23(3):11-27.

Simsek Z, Veiga JF, Lubatkin MH. The impact of managerial environmental perceptions on corporate entrepreneurship: towards understanding discretionary slack's pivotal role. J Manag Stud 2007;44(8):1398-424

Sitkin SB, Pablo AL. Reconceptualizing the determinants of risk behavior. Acad Manage Rev 1992;17(1):9-38.

Sommer SC, Loch $\mathrm{CH}$, Dong J. Managing complexity and unforesseable uncertainty in startup companies: an empirical study. Organ Sci 2009;20(1):118-33.

Sorrentino RM, Roney CJR. The uncertain mind: individual differences in facing the unknown. Philadelphia, PA: Psychology Press; 2000.

Staw BM, Sandelands LE, Dutton JE. Threat-rigidity effects in organizational behavior: a multilevel analysis. Adm Sci Q 1981;26(4):501-24.

Sutcliffe KM. What executives notice: accurate perceptions in top management teams Acad Manage J 1994;37(5):1360-78.

Sutcliffe KM, Huber GP. Firm and industry as determinants of executive perceptions of the environment. Strateg Manage J 1998;19(8):793-807.

Sutcliffe KM, Weber K. The high cost of accurate knowledge. Harv Bus Rev 2003;81(5): $74-82$

Tellis GJ, Prabhu JC, Chandy RK. Radical innovation across nations: the preeminence of corporate culture. J Mark 2009;73(1):3-23.

Thaler RH, Johnson EJ. Gambling with the house money and trying to break even: the effect of prior outcomes on risky choice. Manag Sci 1990;36(6):643-60.

Thomas JB, McDaniel RR. Interpreting strategic issues: effects of strategy and the information-processing structure of top management teams. Acad Manage 1990;33(2):286-306.

Treacy M, Sims J. Take command of your growth. Harv Bus Rev 2004;82(4):127-33.

Tushman ML, Nadler DA. Information processing as an integrating concept in organizational design. Acad Manage Rev 1978;3:613-24.

Tushman ML, O'Reilly CA. Ambidextrous organizations: managing evolutionary and revolutionary change. Calif Manage Rev 1996;38(4):8-30.

Varadarajan PR. Fortune at the bottom of the innovation pyramid: the strategic logic of incremental innovations. Bus Horiz 2009;52:21-9.

Voss GB, Sirdeshmukh D, Voss ZG. The effects of slack resources and environmental threat on product exploration and exploitation. Acad Manage J 2008;51(1):147-64.

Weick KE. Sensemaking in organizations. Thousand Oaks, CA: Sage Publications; 1995

White JC, Varadarajan PR, Dacin PA. Market situation interpretation and response: the role of cognitive style, organizational culture, and information use. J Mark 2003;67(3):63-79.

Wiersema MF, Bantel KA. Top management team turnover as an adaptation mechanism. Strateg Manage J 1993;14:485-504.

Wood MS, McKinley W. The production of entrepreneurial opportunity: a constructivist perspective. Strateg Entrep J 2010;4:66-84.

Wu J, Shanley MT. Knowledge stock, exploration, and innovation: research on the United States electromedical device industry. J Bus Res 2009;62(4):474-83.

Zahra SA. Predictors and financial outcomes of corporate entrepreneurship: an exploratory study. J Bus Venturing 1991;6(4):259-85.

Zahra SA. Environment, corporate entrepreneurship, and financial performance: a taxonomic approach. J Bus Venturing 1993;8(4):319-40.

Zhou KZ, Yim CK, Tse DK. The effects of strategic orientations on technology- and market-based breakthrough innovations. J Mark 2005;69(2):42-60. 